\title{
THE WORK OF THE UNITED STATES CONCILIATION SERVICE IN WARTIME LABOR DISPUTES
}

\author{
John R. SteblmaN*
}

Harmonious labor-management relations have come to have a new significance now that a united America has chosen for its 1942 platform increased, continuous, and all-out production of the arms and supplies necessary to victory. To gain this high goal of production, the President, by Executive Order, named the United States Conciliation Service as the first-line agency to maintain labor-management harmony.

\section{The U. S. Conciliation Service-A Long Established Agency}

The present war situation presents many new problems but the job of settling labor-management disputes by voluntary methods of conciliation and arbitration is not new to the Conciliation Service. As his last official act in March, 1913, President Taft signed the bill creating the Department of Labor which gave the Secretary special conciliation powers. ${ }^{1}$

... the Secretary of Labor shall have power to act as mediator and to appoint commissioners of conciliation in labor disputes whenever in his judgment the interests of industrial peace may require it to be done....

From this simple statement has sprung the activities of a federal service which has operated continuously for twenty-nine years.

The Service has had no compulsory law to enforce and has no police power. And throughout, it has aimed to be a completely impartial agency.

\section{The Significance of Conciliation}

The methods of voluntary mediation and conciliation used by the Conciliation Service are not new. They represent age-old methods of bringing harmony in the midst of conflict. History is filled with the accomplishments of those who have followed the peaceful way of solving problems around the council table. Church councils have ironed out disputes in doctrine. Kings' councils have worked over the major problems of government. Trade associations and labor unions have met

- A.B., r922, Henderson Brown College; A.M., 1924, Ph.B., 1925, Vanderbilt University; Ph.D., 1928, University of North Carolina. Director, United States Conciliation Service, since 1937, Commissioner of Conciliation, 1934-1937. Professor of Sociology and Economics, Alabama College, x9281934. Contributor to periodicals.

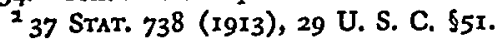


to agree among themselves upon those principles for which they are organized and those working procedures by which they carry on. Indeed, without conciliation and common agreement there would be no government, no industrial organization, no labor unions, and no orderly way of life.

Although the voluntary methods of conciliation and arbitration are not new, their scope and importance to industry have won for them a place of highly increased importance. Good labor relations (now more accurately termed harmonious labor-management relations), is no longer a theoretical subject which may provide future "food for thought." Harmonious labor-management relations today means ships, and tanks, and guns, and planes in abundance and ahead of schedule.

Successful labor-management programs usually consist of a number of important items: the desire for harmonious relations; definite plans for such a program; the establishment of joint labor-management committees to encourage efficiency, harmony, and increased production; the training of foremen to interpret management to labor and labor to management; the pledge of labor and management to attempt to settle all disputes through negotiation and conciliation; and the provision for necessary arbitration machinery to interpret existing contracts and to settle disputes not solved through conciliation.

It has been said that the peaceful, voluntary settlements are not accomplished as rapidly as settlements by economic strength; and that labor-management programs are only successful after continuous and concentrated effort over a long period of time. These facts are undoubtedly true. Evolutionary processes have always taken much longer and have required more patience than have revolutionary processes. However, today our first desire is not speed of settlement but increased and continuous production. Therefore, our problems must be solved at the conference table for although the settlement may not be as speedy as the settlement by economic strength, it can be a settlement without a stoppage of production.

\section{The Organization of the Conciliation Service and the Cases It Handles}

Conciliation, arbitration, and the various special services of the Conciliation Service are carried out by two hundred Commissioners of Conciliation. These men are stationed in the important industrial and commercial centers throughout the country and in the outlying possessions. The assignments are received and their work directed by the Administrative Staff in Washington.

Commissioners of Conciliation are drawn from all walks of life. Some have been personnel managers, industrial relations men, lawyers, labor leaders, employers, and government representatives. In all instances, however, they are chosen for their knowledge and experience in labor-management relations, conference table methods, collective bargaining procedure, and general economics.

For administrative purposes, the Service has divided the country into five regions. Each region has a Regional Supervisor who is in charge of the men of his region. He must assign cases, give advice, direct the work, and provide for the emergency 
situations which arise. The Regional Supervisor is able to maintain such contact by telephone, telegraph, mail, and personal travel.

The Director and Assistant Director supervise the work of the Regional Supervisors, build the policy of the Service, coordinate its activities, and provide for the over-all administrative matters.

Commissioners of Conciliation handle all types of cases: strikes, lockouts, threatened strikes, controversies, and sundry disputes. These cases appear in all the various fields and industries. A Commissioner will come in on a case when requested by a representative of labor, management, or the public. When it is believed to be in the public interest, the Service may offer its assistance without a request.

If the assistance of a Conciliator is sought, a telegram should be sent to the Director of the Conciliation Service, Department of Labor, Washington, D. C., and usually within twelve hours a Conciliator will be on the scene ready to arrange for negotiations.

Since 1913 , the Conciliation Service has handled more than 42,000 situations involving approximately 32 million persons. During $194 \mathrm{r}$, the Conciliation Service disposed of $66 \% 6$ situations directly involving more than $4,625,000$ workers. Of these situations 4725 were actual labor disputes (strikes and lockouts; threatened strikes and controversies) involving more than $3^{1 / 2}$ million workers. During the first eight months of 1942 , the Service handled 7,576 situations. This represents an 87 percent increase over the number of cases handled in the first eight months of I94r.

\section{Techniques of Conciliation}

Conciliation is the peaceful settlement of a dispute through a meeting of minds of the parties concerned. This meeting of minds is accomplished through separate and joint conferences in which the Conciliator, as the impartial party, attempts to bring about a satisfactory settlement. Throughout the life of the Service this method has been used in an ever-increasing way.

The key to conciliation is its voluntary character. The parties to the dispute voluntarily agree to accept the services of a Commissioner of Conciliation. Separate and joint conferences are voluntarily held. And the settlement reached is a voluntary settlement arrived at jointly by the parties to the dispute.

Upon being assigned a case by the Washington office, a Commissioner first interviews the party who has asked for his services. He then proceeds to interview the other individuals and groups involved in order that he may attempt to get a clear picture of the whole situation. After several separate conferences with labor and management, and at the appropriate time, he then attempts to plan a joint conference. Sometimes many joint conferences lasting for extended periods of time, or broken by separate conferences, are necessary before the desired settlement can be reached. In all instances the Commissioner is driving forward with one thought in mind-a solution arrived at by the parties and one which is satisfactory to both 
sides. Through long experience, Commissioners know that the most lasting settlements are ones made through the meeting of minds of the parties directly concerned.

In fact, the great bulk of disputes are settled through intelligent cooperation at the conference table. Miraculous things happen when labor and management agree to sit down together at the same table and discuss their problems. They frequently discover that they have much in common and through these common interests they find a solution to their problems. There are, of course, no blueprints for settlements by conciliation since the types of disputes are legion. What might work today in one place might fail utterly tomorrow in another. This is not difficulty to understand for conciliation is dealing with human nature and it is variable.

In addition to regular conciliation procedures, a more concentrated form of conciliation, termed by the Service "the panel method," has been used increasingly in the war effort. This method of handling cases was an old custom of the Service which involved inviting to Washington the parties to serious disputes of critical national importance which had not been solved by a Commissioner in the field. The parties then appeared before a panel of three Commissioners where new and concentrated techniques were employed.

After the creation of the National Mediation Board in March, I94I, it was decided to increase the use of the panel method in order to prevent a backlog of unsettled cases. Most of these panel cases were either in the strike or threatened strike stage and involved production or transportation vital to the defense effort. The main issues involved were generally wages, recognition, overtime, and vacations. The War Labor Board, upon its creation, suggested a continuance of the panel method because of the record it had made in the past. The Service agreed to continue this practice but instead of calling the parties to the dispute to Washington, the panel meetings are now held at various places in the field.

\section{Arbitration}

Voluntary arbitration has been a function of the United States Conciliation Service ever since the Service was established in I9r3. Throughout the years since that time, with an ever-increasing number of arbitration assignments, Commissioners have served as arbitrators in situations involving almost every aspect of employeremployee relations.

Voluntary arbitration is, of course, quite different from conciliation. Arbitration is the adjudication of a disputed point by a third party who makes an award or decision which the parties have previously agreed to accept.

The Conciliation Service is actually engaged in official and private arbitration. In official arbitration, a Commissioner of Conciliation with specific arbitration training is appointed at the joint request of the parties involved. In private arbitration, the Director, at the joint request of the parties, appoints an outside arbitrator from a panel compiled by the Conciliation Service. This panel consists of several hundred names of private public-spirited citizens who have done arbitration work or who have special qualifications in the field. 
An arbitrator, either from the staff of the Conciliation Service or as a public member appointed by the Director of the Conciliation Service, does not proceed with a case until both parties have signed a statement agreeing to accept his services and to abide by his decision. After the submission is signed, the arbitrator then calls the parties together to hear the case. Arbitration hearings are usually conducted on the basis of oral testimony and documentary evidence. And the parties also are granted the right to submit briefs.

There are now two principal types of arbitration. The first type is the interpretation of a disputed point of an existing agreement. This type of arbitration is becoming more important with the ever-increasing number of labor-management contracts. Because the parties, at the signing of complicated contracts, are not always clear on the meaning of certain provisions, they are increasingly providing in their agreements that if they are at any time unable to adjust a dispute over interpretation of any part of the contract, the matter shall be submitted to arbitration. It is frequently provided that the Conciliation Service, upon request, will designate the arbitrator. A survey last year of twelve hundred agreements in the files of the Conciliation Service disclosed that $62 \%$ contained provisions for arbitration.

The second principal type of arbitration is conducted to form policy where an agreement does not exist or where a new contract is being negotiated. Unlike "arbitration of interpretation," where the case has probably gone directly to arbitration, in "policy forming arbitration outside an agreement," conciliation has usually been tried and arbitration is resorted to only after conciliation has been deadlocked.

Although voluntary arbitration has long played a vital role in settling labormanagement disputes in America, at no time has it been as important or as widely used as in the present war effort. This is largely due to the agreement arrived at following the attack on Pearl Harbor at the President's labor industry conference. In labor-management's "no strike or lockout" pledge given at this conference, the representatives promised to settle all disputes by direct negotiation, conciliation or arbitration.

Therefore, in order to maintain the continuous and all-out production so necessary to our war effort, the age-old technique of arbitration is playing an important part in the rapid and judicial settlement of many controversies.

\section{Technical Service}

If an agreement on a particular point has not been reached through conference table negotiation, the Commissioner of Conciliation may suggest that the disputed point might be satisfactorily adjusted if an impartial study or survey of the question were conducted.

The Conciliation Service has a number of Commissioners with technical training who are equipped to make various types of surveys and studies if requested by both parties to a dispute. The methods employed by these technically trained Commissioners, of course, depend upon the question involved. Observation studies are 
made to determine the actual amount of work being performed when there is an alleged overwork load. Surveys are sometimes made of competitive plants to form a basis of settling a dispute when workers contend that the conditions in their plant do not favorably compare with competitive plants. In such cases, data must be gathered and compiled on job descriptions, job assignments, and average hourly earnings. Reviews are made at times of present job evaluation setups when incorrect evaluation is charged. And these technically trained men often act as the impartial members of fact-finding or job evaluating committees.

The work of these technically trained Commissioners of Conciliation is supervised by the Technical Adviser to the Service.

\section{Conciliation Service Cooperates with the War Effort}

Throughout the period of the defense program, and of course, now in our war effort, the Conciliation Service has placed primary emphasis upon the promotion of industrial peace in operations vitally affecting our defense and war programs. It has sought to do this in a definitely designed program within the Service and by cooperating with various other governmental agencies vitally concerned with labormanagement peace.

Since the beginning of our emergency program, the Service has maintained a liaison Commissioner between the Conciliation Service and the War and Navy Departments, the War Production Board, the National Defense Mediation Board and the present National War Labor Board. The cooperation received from these agencies has made it possible for the Conciliation Service to settle all but a limited number of the most difficult disputes.

In order to establish a definite policy for the settlement of labor-management disputes and to provide further mediation machinery, the President issued an Executive Order on January I2, I942. This Order creating the National War Labor Board set forth three steps for adjusting and settling labor-management disputes "which might interrupt work which contributes to the effective prosecution of the war": first, direct negotiations by the parties involved; second, conciliation by the United States Conciliation Service; third, mediation or arbitration by the National War Labor Board.

A program of "working cooperation" has existed between the Conciliation Service and the War Labor Board from the time the Board was established. Conferences between the Board and the Service were held immediately after the creation of the Board and a coordinated policy was established for handling disputes. It was decided that prior to the certification of any dispute to the Board, a Commissioner of Conciliation would be assigned to each dispute involving production or transportation of defense materials, and that this Commissioner would remain with the case until it was either settled or deadlocked. In case the Board desires it, the Commissioner of Conciliation might continue the negotiation of the case even after certification. 
The War Labor Board is authorized to act when the Secretary of Labor certifies a dispute "which might interrupt work which contributes to the effective prosecution of the war" and which has not been promptly settled by the Conciliation Service. The Executive Order also states that the Board may enter a case at its own discretion after consultation with the Secretary of Labor. However, in actual practice the Board has not taken cases on its own motion. The Board has handled only cases which have been certified to it by the Secretary after settlement has been attempted by the Conciliation Service. This practice has been established, contrary to the thought of some, at the request of the War Labor Board. It was the Board's desire in order to avoid a needless backlog of cases and to best serve the nation by handling a limited number of cases quickly and effectively.

\section{Increased Labor-Management Cooperation}

Since the declaration of war there have been many evidences that labor and management are cooperating and are using the available mediation, conciliation, and arbitration machinery.

Immediately following the attack on Pearl Harbor, labor-management groups throughout the country pledged their full cooperation to the war effort and promised to maintain continuous production by using available mediation machinery to settle their grievances. And as this labor-management cooperation went into effect, there was a sharp and substantial decrease in the number and duration of stoppages.

This pledged cooperation was further established at the labor-industry conference called by the President December 17 . Here labor and management pledged "no strikes or lockouts" for the duration of the war. Before the House Naval Affairs Committee on March 26, 1942, labor again emphasized its pledge of "no strikes for any cause for the duration."

The importance of these pledges was emphasized by the President on February 23, when he said "We shall not stop work for a single day. If any dispute arises we shall keep on working while the dispute is solved by mediation, conciliation or arbitration-until the war is won."

As the period since the declaration of war is viewed, it is seen that although war industry employment has increased rapidly, the time lost due to strikes was only seven one-hundredths of one percent. In other words, the pledge of cooperation has worked 99.93 percent effective.

Last year the average length of strikes was about ten days while this year, the average duration of strikes is about two days. Workers are mostly back on the job the day after the strike. As we compare the time lost through strikes with the time lost through accidents and illness we find that five times as many man-days were lost from colds and respiratory diseases last year as through strikes. Also, twelve times as many man-days were lost from industrial accidents as were lost through work stoppages.

Looking at the picture throughout the record of the Conciliation Service we 
find an increased case load. Previous to the declaration of war, the active daily case load of the Service averaged about six hundred. In the last eight months, this daily case load has been tripled. This increase, however, is not an indication of a national increase of strikes but rather it is an indication of increased labor-management cooperation. In other words, there is now a sincere desire to present cases for negotiation at an early stage of the dispute. It is then possible to use preventive measures. Therefore, almost all of the cases are being settled without any stoppage of work and thus without any harm to the war effort. An example of this is the record of the Service during the last fiscal year. In this time the Service handled 4,185 threatened strikes and controversies and settled over $94 \%$ without any stoppage of work.

To meet the task ahead, however, we know that even one stoppage, no matter how small or for what short duration, is one too many. In order to handle those few cases which have already reached the stoppage stage and the large number of cases in the threatened strike or controversy stage, it has been necessary to increase the staff of Commissioners and for the Service to operate on an almost twenty-fourhour day basis. Even so, this means that Commissioners of Conciliation must carry a load of five to fifteen cases simultaneously. In spite of this heavy load, during the first eight months of this year, 5,744 labor disputes were settled by Commissioners of Conciliation while only 434 cases were certified to the War Labor Board.

\section{The Task Ahead}

In spite of notable labor-management cooperation and the all-out efforts of established agencies to bring peace without work stoppage, there is still a tremendous task ahead. As President Roosevelt stated on February 23, "We are coming to realize that one extra plane, or extra tank, or extra gun, or extra ship completed tomorrow may, in a few months turn the tide on some distant battlefield; it may make the difference between life and death for some of our fighting men."

This task looms even larger when we realize that we are continually having new problems to meet. A year ago our problems were rising living costs and desire for union security. Today we have these problems and problems of conversion, material shortages, lack of skilled men, contracts for small business, and many others.

Therefore, in order to meet our goals of unprecedented proportions and to be victorious, it will be necessary to utilize all of our resources, our manpower, our machines, and our ingenuity. And we will need the full cooperation of labor and management and unlimited assistance of 130 million Americans. 